\title{
Okul Öncesi Dönem Çocuklarının Öz Düzenleme Becerileri ile Benlik Algıları Arasındaki İlișkinin İncelenmesi
}

\author{
Dr. Öğr. Üyesi Necla Tuzcuoğlu ${ }^{1}$ \\ Öğr. Gör. Kadriye Efe Azkeskin ${ }^{2}$ \\ Arş. Gör. Gülşen İlçi Küsmüş̧ \\ Arş. Gör. Özge Cengiz ${ }^{4}$
}

Gelis tarihi: 01.09.2019

Kabul tarihi: 07.10.2019

\section{Atıf bilgisi:}

IBAD Sosyal Bilimler Dergisi

Sayı: Özel Sayı Sayfa: 607-623

Yıl: 2019

This article was checked by Turnitin. Similarity Index $11 \%$.

\footnotetext{
${ }^{1}$ Marmara Üniversitesi, Türkiye, necla.tuzcuoglu@marmara.edu.tr ORCID ID 0000-0002-2864-2422

${ }^{2}$ Marmara Üniversitesi, Türkive, ekadriye@marmara.edu.tr

ORCID ID 0000-0002-3041-500X

$3^{*}$ Marmara Üniversitesi, Türkive, gulsen.ilci@marmara.edu.tr ORCID ID 0000-0003-2885-1176

${ }^{4}$ Marmara Üniversitesi, Türkiye,
} ozge.cengiz@marmara.edu.tr ORCID ID 0000-0003-0628-3825

\footnotetext{
* Sorumlu yazar
}

ÖZ

Okul öncesi dönem çocukları içinde bulundukları aile ve çevrede kazandıkları deneyimler yoluyla, günlük yaşamda karșılaștıkları problemleri izleme, tahminlerde bulunma, planlamalar yapma gibi adımlarla çözmeye çalışırlar. Duygu ve davranışlarında kendini kontrol etme ve düzenleme becerileri kazanan çocukta, olumlu benlik algısının oluşumu desteklenebilir. Dolayısıyla çocuklarda olumlu benlik algısının geliștirilmesi ve desteklenmesi açısından, söz konusu iki kavramın birbirlerine etkileri üzerine araştırmalar yapılması gerektiği düşünülmektedir. Bu nedenle araştırmanın amacını; okul öncesi dönem çocuklarının öz düzenleme becerileri ile benlik algıları arasındaki ilișkisinin incelenmesi ve çocukların öz düzenleme becerileri ile benlik algılarının demografik özelliklere göre (cinsiyet, yaş, kardeş sayısı, anne ve baba öğrenim durumu, okul öncesi eğitim kurumuna devam etme süresi) incelenmesi oluşturmuştur. Araştırmanın çalışma grubunu; devlete ait okul öncesi kurumuna devam etmekte olan 220 çocuk olușturmaktadır. Araștırmada veri toplama aracı olarak, "Öz Düzenleme Becerileri Ölçeği” ve "DeMoulin Çocuklar İçin Benlik Algısı Ölçeği” uygulanmıştır. Araştırma sonucunda, okul öncesi dönem çocuklarının öz düzenleme becerileri ile benlik algıları arasında orta düzeyde ve pozitif yönde anlamlı bir ilişki bulunmuştur. Ayrıca çocukların öz düzenleme becerilerinin cinsiyet, yaş ve okul öncesi eğitim kurumuna devam etme süresi değişkenlerine göre farklılık gösterdiği tespit edilmiştir. Çocukların benlik algılarının ise anne ve baba öğrenim durumu ve okul öncesi eğitim kurumuna devam etme süresi değişkenlerine göre farklılık gösterdiği tespit edilmiştir.

Anahtar Kelimeler: okul öncesi dönem çocukları, öz düzenleme becerisi, benlik algis1. 


\title{
Analyzing the Relationship between Preschool Children's Self-Regulation Skills and Self-
} Perception

\author{
Dr. Öğr. Üyesi Necla Tuzcuoğlu ${ }^{1}$ \\ Öğr. Gör. Kadriye Efe Azkeskin ${ }^{2}$ \\ Arş. Gör. Gülșen İlçi Küsmüş ${ }^{3 *}$ \\ Arş. Gör. Özge Cengiz ${ }^{4}$
}

First received: 01.09.2019

Accepted: 07.10.2019

\section{Citation:}

IBAD Journal of Social Sciences

Issue: Special Issue Pages: 607-623

Year: 2019

This article was checked by Turnitin. Similarity Index $11 \%$.

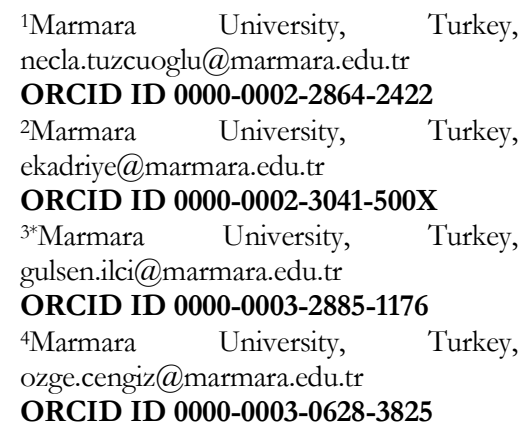

* Corresponding Author

\begin{abstract}
Preschool children try to solve the problems they encounter in daily life through predicting and planning by means of experiences gained in the family and the environment they live in. The formation of positive self-perception can be supported in the child who gains self-control and regulation skills in emotions and behaviors. Therefore, in terms of developing and supporting positive self-perception in children, it is thought that researches should be done on the effects of these two concepts on each other. In this reason; the aim of this research is to analyze the relationship between preschool children's self-regulation skills and self-perceptions and also to examine children's self-regulation skills and self-perceptions in terms of demographic characteristics (gender, age, number of siblings that they have, educational status of their mother and father, period of attending pre-school education). As a result of research, a significant positive moderate correlation was found between preschool childrens' self-regulation skills and self-perceptions It was also determined that preschool children's self-regulation skills significantly differ according to their gender, age and period of attending pre-school education; childrens' self-perception also significantly differ according to educational status of their mother and father and period of attending pre-school education age.
\end{abstract}

Keywords: preschool children, self-regulation skills, self-perception. 


\section{GİRIŞ}

Okul öncesi dönem çocuğun en üst düzeyde gelişim gösterdiği, merak ve düşünme potansiyeli ile öğrenmelerini gerçekleştirdiği kritik bir dönemi içermektedir. Bu dönemde çocuğun öğrenmeleriyle kazandığı deneyimler yetişkinliğe kadar olan yaşamında bir temel teşkil eder (Senemoğlu, 1994; Kartal, 2007). Bu nedenle okul öncesi eğitim çocuk için son derece öneme sahiptir. Okul öncesi eğitim çocuğun tüm gelişim alanlarını (bilişsel, dil, motor, sosyal ve duygusal gelişimleri ile öz bakım becerilerini) desteklemek için gerekli, gelişimsel özelliklerine ve bireysel farklılıklarına uygun, içsel potansiyelini ortaya çıkarmasına yardımcı bir eğitim sürecidir (Kuru-Turaş11, 2014). Okul öncesi dönemi de içine alan çocukluk yıllarında çocuk potansiyelini açığa çıkarırken belli başlı becerileri de kazanır. Bu becerilerden bir tanesi de öz düzenleme becerisidir.

Öz düzenleme becerisi, farklı şekillerde tanımlanmaktadır. Sosyal-bilişsel teoristlere göre öz düzenleme becerisi; çocuğun aktif şekilde öğrenme katılımını ailesinin, öğretmeninin ya da diğer talimat içeren etmenlerin varlığı olmadan gerçekleştirebilmesidir (Zimmerman, 1989). Zimmerman öz düzenlemeyi, bireylerin sadece çevre ile ilgili olaylarda kendi davranışlarını yürütme becerisi olarak değil, aynı zamanda bu beceriyi uygun koşullarda kullanabilmek için gerekli bilgi edinme zorunluluğu olarak ifade etmektedir. Ona göre öz düzenleme; kişisel amaçlara ulaşmada planlanan ve yönlendirilen düşünceler, duygular ve eylemleri içermektedir (Zimmerman, 2000).

Bu duygu ve düşünceler için Vygotsky zihinsel araçlar ifadesini kullanmıştır. İnsanların çekiç, kaldıraç gibi fiziksel araçları fiziksel kapasitelerini arttırmak için icat ettiği gibi, zihinsel yetenekleri için de zihinsel araçları kullandıklarına dair bir açıklama getirmiştir. Çünkü zihinsel araçlar dikkati toplama, hatırlama ve düşünme becerilerinde yardımcı görev üstlenmektedir. Vygotsky; dikkati, hatırlamayı ve düşünmeyi değiştirmede zihinsel araçların önemini vurgulamıştır (Bodrova, Germeroth ve Leong, 2013).

Sosyo-kültürel teoristler çocukların davranışlarını kişisel ve durumsal hedeflerinin zorluğunu yenerken izleme, kontrol etme, rehberlik ve planlama yaparak düzenlediğini ve bu davranışların öz düzenlemeyi meydana getirdiğini tartışmışlardır (Campbell, 1997; Diaz, Neal ve Amay-Williams, 1990; Akt.Grolnick ve Farkas, 2002). Duygu ve davranışların düzenlenmesinde önemli bir faktör olan öz düzenleme becerisi bebeklikten başlayarak yetişkinlik dönemine kadar aile ve çevrenin etkisiyle değişmektedir (Kochanska, Coy ve Murray, 2001).

Öz düzenleme becerisi, çocuğun davranış kontrolü, duygu yönetimi, dikkat ve dikkati sürdürebilme becerileri olarak tanımlanmaktadır (Shonkoff ve Phillips, 2000). Öz düzenleme becerisinin erken yıllarda desteklenmesi; çocukların hem okul hem de gündelik yaşantılarında karşılaştıkları problemlerin çözümünde gayret göstermeleri, farklı güçlüklere karşı mücadele etmeleri ve stresle başa çıkabilmede izlenecek yolları bulamaları ve kendilerine olan güvenleri açısından önem taşımaktadır (Schunk ve Zimmerman, 2001). Bu nedenle yaşamın ilk yılları öz düzenleme becerisi için kritik dönemi içermektedir diyebiliriz. Bu dönemde kazanılan öz düzenleme becerisi kalıcı olmakta ve öz düzenlemenin temelini oluşturmaktadır. Çocuklarda görülen davranış değişikliklerinin köşe taşı olan öz düzenleme becerisinin, çocukların benlik algısını da etkileyebileceği muhtemeldir.

Bireyin toplumla ve çevresiyle olan ilişkilerinin şekillenmesinde onlarla kurduğu etkileşimin birey üzerindeki etkisi kadar bireyin kendine ilişkin görüşleri de önemli rol oynamaktadır. Bireyin kendine ilişkin görüşleri benlik algısı kavramı ile nitelendirilmekte ve bu kavramı açıklarken psikolojik, sosyolojik ve fizyolojik etkenlerin karşlıklı etkileşimi merkeze alınmaktadır (Zembat, Koçyiğit, Akşin Yavuz ve Tunçeli, 2018).

Benlik algısı; bireyin hayat boyunca yaşadığı olumlu veya olumsuz tüm deneyimler ile bu deneyimlerine yüklediği yargıların tümü olarak tanımlanmaktadır (Demoulin, 1999). Bee ve Boyd (2009) benliği, bireyin kendi benliğine atfettiği özellikler üzerindeki duygu, düşünce ve bilgileri olarak belirtmiştir. Başka bir tanımda benlik kavramı, çocuğun kendisi ile ilgili kafasındaki algıdır. Bu, çocuğun içine kapalı ya da girişken olmasını, güvenli olup olamayacağını belirlemektedir. Çocuğun benliği doğuştan gelen bir özellik olmayıp dünyayı seyrettiği bir gözlük gibidir ve başkalarıyla ilişkilerden ya da kendi duygu ve düşüncemizle ortaya çıkar. Başarı ya da başarısızlıkla okul yaşantılarından, uygun davranışı gösterme ile yaşıtlarından, sevgi ve disiplin ile anne-babadan ve bir takım başka olaydan etkilenir (Yorulmaz, 2017). 
Benlik algısına yönelik ülkemizde yapılmış araştırmalar incelendiğinde; söz konusu kavramın sosyal gelişim alanı ile ilgili konular ile birlikte ele alındığı ve ilişkisel boyutta incelendiği çalışmalara (Gizir ve Baran, 2002; Polat ve Akşin, 2015) rastlanmıştır. Ayrıca benlik algısının cinsiyete göre farklılaştığını bulgulayan araştırmalar (Bosacki, 2007; Sarıca, 2010; Şanlı, 2012; Akşin-Yavuz, Güven, Bayındır, Sezer ve Yılmaz, 2016) olduğu gibi; cinsiyete göre herhangi bir farkın olmadığını belirleyen araştırmalar (Kuru-Turaşl1, 2006; Zincirkıran, 2008; Dündar, 2010; Yakupoğlu, 2011) da mevcuttur. Öz düzenleme becerisi ile ilgili yapılmış olan araştırmalara bakıldığında; Bondurant (2010) akademik başarısızlık ile öz düzenleme arasındaki ilişkiyi incelerken aynı zamanda 36-54 ay arasındaki çocukların öz düzenleme becerilerindeki eksiklikleri de belirlemeye çalışmışır. Akawi (2011) öz düzenleme ile ilköğretime hazır bulunuşluk kavramlarını birlikte ele alarak bir araştırma yürütmüştür. Fındık-Tanrıbuyurdu (2012) çalışmasında Okul Öncesi Öz Düzenleme Ölçeği'ni geliştirmiştir. Ertürk-Kara ve Gönen (2015) okul öncesi dönem çocuklarının öz düzenleme becerilerini yaş, cinsiyet, doğum sırası gibi çeşitli değiş̧kenlere göre incelemiştir. Aksoy ve Tozduman-Yaralı (2017); çocukların öz düzenleme becerileri ile oyun becerilerini cinsiyete göre incelemiştir.

Benlik algısı ve öz düzenleme kavramlarının birbiriyle dolaylı olarak ilişkili olabileceği düşünülebilir. Okul öncesi dönem çocukları içinde bulundukları aile ve çevrede kazandıkları deneyimler yoluyla, günlük yaşamda karşılaştıkları problemleri izleme, tahminlerde bulunma, planlamalar yapma gibi adımlarla çözmeye çalışabilirler. Bu aşamalar çocukların öz düzenleme becerilerinin gelişmesine katkıda bulunabilir. Duygu ve davranışlarında kendini kontrol etme ve düzenleme becerileri kazanan çocukta olumlu benlik algısının oluşumu desteklenebilir. Dolayısıyla çocuklarda olumlu benlik algısının geliştirilmesi ve desteklenmesi açısından, söz konusu iki kavramın birbirlerine etkileri üzerine araştırmalar yapılması gerektiği düşünülebilir. İlgili alan yazın incelendiğinde ülkemizde okul öncesi dönem çocuklarının öz düzenleme becerileri ve benlik algılarının birlikte ele alındığı bir çalışmaya rastlanmamıştır. Tüm bu nedenlerden dolayı araştırmanın amacını; okul öncesi dönem çocuklarının öz düzenleme becerileri ile benlik algıları arasındaki ilişkisinin incelenmesi oluşturmuş ve aşağıdaki sorulara yanıt aranmıştır:

- Okul öncesi dönem çocuklarının öz düzenleme becerileri ile benlik algıları arasında anlamlı bir ilişki var midir?

- Okul öncesi dönem çocuklarının öz düzenleme becerileri ile benlik algıları demografik özelliklere göre (çocuğun cinsiyeti, yaşı, kardeş sayısı, annenin öğrenim durumu, babanın öğrenim durumu, okul öncesi eğitim kurumuna devam etme süresi) anlamlı bir farklılık göstermekte midir?

\section{YÖNTEM}

\section{Araştırma Modeli}

Araştırmada nicel araştırma türlerinden ilişkisel tarama modeli kullanılmıştır. Tarama modelleri; bir grubun belirli özelliklerini belirlemek için yapılan araştırmalardır. Tarama modelleri içinde yer alan ilişkisel (korelasyonel) araştırma ise; iki ya da daha fazla değişken arasındaki ilişkileri belirlemek ve neden-sonuç ile ilgili ipuçları elde etmek amacıyla yapılan araştırma türünü ifade etmektedir (Büyüköztürk, Kılıç-Çakmak, Akgün, Karadeniz ve Demirel, 2016). Bu araştırmada da okul öncesi dönem çocuklarının öz düzenleme becerileri ve benlik algıları arasındaki ilişki incelendiğinden, tarama modeli esas alınmıştır.

\section{Çalışma Grubu}

Araştırmanın çalışma grubunu 2018-2019 eğitim öğretim yılında İstanbul ili Kadıköy ilçesinde bulunan devlete ait okul öncesi eğitim kurumlarına devam eden 220 çocuk oluşturmaktadır. Çalışma grubunun belirlenmesinde seçkisiz olmayan örnekleme yöntemlerinden uygun örnekleme yönteminden yararlanılmıştır. Uygun örnekleme yönteminde ekonomiklik esastır. Bu tür örnekleme araştırmacıya tanıdık çevresinden örnekleme alma imkanı verir (Balcı, 2001). Bu çalışmada; İstanbul ili için ulaşım göz önünde bulundurularak okullara ulaşımın kolay olması ve çocuklarla birebir çalışılması söz konusu olduğundan; uygun örnekleme yöntemi tercih edilmiştir. Çalışma grubuna ait demografik özellikler Tablo 1'de sunulmuştur. 
Tablo 1. Çalışma grubuna ait demografik bilgiler

\begin{tabular}{|c|c|c|c|c|c|}
\hline Çocuğun Cinsiyeti & f & $\%$ & Anne Öğrenim Durumu & f & $\%$ \\
\hline \multirow{4}{*}{$\begin{array}{c}\text { Kiz } \\
\text { Erkek } \\
\text { Toplam }\end{array}$} & \multirow{4}{*}{$\begin{array}{c}92 \\
122 \\
214\end{array}$} & \multirow{4}{*}{$\begin{array}{c}43 \\
57 \\
100\end{array}$} & İlkokul ve Ortaokul & 41 & 19,2 \\
\hline & & & Lise & 61 & 28,5 \\
\hline & & & Üniversite & 112 & 52,3 \\
\hline & & & Toplam & 214 & 100 \\
\hline Çocuğun Yaşı (Ay) & f & $\%$ & Baba Öğrenim Durumu & f & $\%$ \\
\hline $48-60$ & 105 & 491 & İlkokul ve Ortaokul & 40 & 18,7 \\
\hline $\begin{array}{l}40-00 \\
61-72\end{array}$ & 100 & $\begin{array}{l}49,1 \\
500\end{array}$ & Lise & 62 & 29 \\
\hline $61-72$ & 109 & 50,9 & Üniversite & 112 & 52,3 \\
\hline 10pam & 214 & 100 & Toplam & 214 & 100 \\
\hline Kardeş Sayısı & $\mathbf{f}$ & $\%$ & $\begin{array}{l}\text { Okul Öncesi Eğitim Kurumuna Devam } \\
\text { Etme Süresi }\end{array}$ & f & $\%$ \\
\hline Tek Çocuk & 73 & 34,1 & 1 & 91 & 42,5 \\
\hline 1 kardeş & 102 & 47,7 & 2 & 87 & 40,7 \\
\hline 2 ve üstü kardeş & 39 & 18,2 & 3 & 36 & 16,8 \\
\hline Toplam & 214 & 100 & Toplam & 214 & 100 \\
\hline
\end{tabular}

Tablo 1'e bakıldığında araştırmaya katılan çocukların \%43'ü kız \%57'si erkektir. Çocukların \%49'u 48-60 ay, \%51'i 61-72 ay yaş aralığına sahiptir. Araştırmaya katılan çocukların \%34,1'i tek çocuktur. Çocukların \%47,7'si 1 kardeşe, \%18,2'si 2 ve üstü kardeşe sahiptir. Annelerin \%19,2'sinin ilkokul ve ortaokul, \%28,5'i lise ve \%52,3'ünün üniversite düzeyinde öğrenim durumunda olduğu görülmektedir. Babaların öğrenim durumlarına bakıldığında; \%18,7'sinin ilkokul ve ortaokul, \%29'unun lise ve $\% 52,3$ 'ünün üniversite mezunu olduğu görülmektedir. Araştırmaya katılan çocukların \%42,5'i okul öncesi eğitim kurumuna 1 y11, \%40,7'si 2 y1l ve \%16,8'i 3 y1l boyunca devam etmektedir.

\section{Veri Toplama Araçları}

\section{Kişisel Bilgi Formu}

Araştırmacılar tarafından geliştirilen formda; çocukların cinsiyeti, yaşı, kardeş sayısı, anne ve baba öğrenim durumu ve okul öncesi eğitim kurumuna devam etme sürelerine yönelik sorular bulunmaktadır.

\section{Öz Düzenleme Becerileri Ölçeği}

Öz Düzenleme Becerileri Ölçeği Bayındır ve Ural tarafından (2016) geliştirilmiştir. Çocukların öz düzenleme becerilerini ölçmeyi amaçlayan ölçek 5'li likert tipinde ve 33 sorudan oluşmaktadır. Ölçekteki maddeler, "kesinlikle doğru”, "doğru”, "kısmen doğru", "doğru değil” ve "kesinlikle doğru değil" şeklinde belirtilen beşli dereceleme şeklinde düzenlenmiştir. Ölçekte iki faktör bulunmaktadır: Birinci faktör "düzenleme becerileri" İkinci faktörü ise "kontrol becerileri" adı altında toplanmıştır. Faktör analizi sonunda ilk faktörün 21 maddeden oluştuğu, ikinci faktörün ise 12 maddeden oluştuğu sonucuna ulaşılmıştır. Ölçme aracının güvenirliğini değerlendirmek amacıyla iç tutarlılık katsayısı (Cronbach's Alpha); düzenleme becerileri alt boyutu için: .96, kontrol becerileri alt boyutu için: .91 ve ölçeğin tamamı için .96 olarak hesaplanmıştır. Bu bulgular doğrultusunda ölçme aracının geçerli ve güvenilir olduğu sonucuna ulaşılmıştır (Bayındır ve Ural, 2016).

\section{DeMoulin Çocuklar İçin Benlik Algısı Ölçeği}

Demoulin (1998) tarafından, çocukların bireysel benlik kavramının sistematik ve karşılaştırmalı analiz etme ve tanı koyma amacıyla geliştirilmiş olan "DeMoulin Çocuklar İçin Benlik Algısı Ölçeği” ilk olarak Kuru-Turaşlı (2006) tarafından doktora tez çalışması kapsamında Türkçe'ye uyarlanmıştır. 2014 yılında yine Kuru-Turaşlı tarafından ölçeğin geçerlik ve güvenirlik çalışması yapılmıştır. 29 madde olarak 60-72 aylık çocuklar için geçerli-güvenilir bir ölçme aracı olarak belirlenmiştir. Ardından 2016 yılında Zembat vd. (2016) tarafından ölçeğin 36-72 aylık çocuklar için geçerlik güvenirlik çalışması yapılmıştır.

Yapılan analizler sonucu ölçek; "Öz Saygı" (14 madde) ve "Öz Yeterlilik" (14 madde) olmak üzere iki alt boyut ve toplam 28 maddeden oluşmuştur. Ölçeğin toplam güvenirlik katsayısı .81 olarak; alt 
boyutlarda ise öz yeterlik için .68 ve öz saygı için de .68 olarak hesaplanmış ve ölçeğin 36- 72 ay yaş grubundaki çocuklara yönelik geçerli ve güvenilir bir ölçme aracı olduğu belirtilmiştir. Ölçek maddeleri her biri bir durumu betimleyen ve kısa cümlelerden oluşmaktadır. Her bir duruma yönelik çocuklardan alınan yanıtlar; her gülen yüz için 3 puan, her ifadesiz yüz için 2 puan ve her mutsuz yüz için 1 puan şeklinde değerlendirilmektedir.

\section{Verilerin Toplanması}

Verilerin toplanması sürecinde, belirlenen okul öncesi eğitim kurumlarında uygulama yapabilmek üzere İl Millî Eğitim Müdürlügünden gerekli izinler alınmıştır Araştırmanın yapıldığı Kadıköy ilçesindeki okullara gidilmiş kullanılan ölçeklerden öz düzenleme ölçeği çocuklar adına öğretmenlerin doldurması için öğretmenlere elden dağıtılmış ve doldurulduktan sonra teslim alınmıştır. Uygulama öncesi öğretmenlere araştırmanın önemi ve eğitime olan katkısı açıklanmış; bu nedenle içtenlikle sorulara cevap verilmesinin araştırma sonuçları için önemli olduğu belirtilmiştir. Çocuklarla yapılan bire bir görüşmeler için ise sessiz ve dikkat dağıtıcı uyaranlardan arındırılmış bir ortam hazırlanmış; araştırmacılar tarafından "Demolin Çocuklar için Benlik Algısı Ölçeği" çocuklara bire bir uygulanmıştır. Veriler Nisan-Mayıs ayları arasında toplanmıştır.

\section{Verilerin Analizi}

Araştırmadan elde edilen veriler istatistik paket programı ile analiz edilmiştir. Çocukların demografik özelliklerine ilişkin verilerin frekans ve yüzde değerleri hesaplanmıştır. Elde edilen verilerin normal dağılım gösterip göstermediğine Kolmogorov-Smirnov (K-S) testi ile bakılmış ve dağılımın normal olduğu görülmüştür $(\mathrm{p}>.05)$. Normal dağılan verilerin analizinde kullanılan parametrik yöntemlerden yararlanılmıştır. Okul öncesi dönem çocuklarının saldırganlık yönelimleri ile anne-baba ilgisi puanları arasındaki ilişkiyi incelemek üzere Pearson momentler çarpımı korelasyon katsayısı analizi kullanılmıştır. Köklü, Büyüköztürk ve Bökeoğlu (2006)'na göre, korelasyon katsayısının gücü; 0.010.29 arasında ise düşük düzeyde ilişki, 0.30 - 0.70 arasında ise orta düzeyde ilişki, 0.71- 0.99 arasında ise yüksek düzeyde ilişki ve 1.00 ise mükemmel ilişki verilen aralıklarla belirlenebilmektedir. Ölçek puanlarının cinsiyet ve yaş değişkenine göre farklılaşıp farklılaşmadığını belirlemek üzere bağımsız gruplar t-testi, kardeş sayısı, anne ve baba öğrenim durumu ve okul öncesi eğitim kurumuna devam etme süresi değişkenlerine göre farklılaşıp farklılaşmadığını belirlemek üzere tek yönlü varyans analizi (ANOVA) uygulanmıştır. Farklılıkların yönünü belirlemek üzere Post-Hoc analizlerinden (Scheffe Testi, Tamhane testi) yararlanılmıştır. Veriler istatistik paket programında çözümlenmiş ve anlamlılık düzeyi .05 olarak değerlendirilmiştir.

\section{BULGULAR}

$\mathrm{Bu}$ bölümde araştırma sorularını açıklayan istatistiksel analizlere yer verilmiştir.

Tablo 2. Öz Düzenleme Becerileri ile Benlik Algısı Ölçek Puanları Arasındaki İlişkiye Ait Pearson Çarpım Momentler Korelasyon Katsayısı Sonuçları

\begin{tabular}{cccccc}
\hline Değişkenler & $\mathbf{N}$ & $\overline{\boldsymbol{X}}$ & $\mathbf{s s}$ & $\mathbf{r}$ & $\mathbf{p}$ \\
\hline $\begin{array}{c}\text { Öz Düzenleme Becerisi } \\
\text { Benlik Algısı }\end{array}$ & 214 & 111,9 & 16,36 & \multirow{2}{*}{, 32} & \multirow{2}{*}{, $00^{* * * *}$} \\
\cline { 2 - 4 }$p^{* *}<.001$ & 214 & 71,5 & 6,85 & &
\end{tabular}

Tablo 2'ye göre okul öncesi dönem çocuklarının öz düzenleme becerileri ile benlik algıları arasında orta düzeyde ve pozitif yönde anlamlı bir ilişki bulunmuştur $(\mathrm{p}<.001 ; \mathrm{r}=, 32)$. Bu sonuca göre; çocukların öz düzenleme becerileri arttıkça benlik algıları da arttığı söylenebilir. 
Tablo 3. Okul Öncesi Dönem Çocuklarının Öz düzenleme Becerileri ve Benlik Algılarının Cinsiyet Değişkenine Göre Farklılaşma Durumuna İlişkin Yapılan Bağımsız Gruplar t-Testi Sonuçları

\begin{tabular}{|c|c|c|c|c|c|c|c|}
\hline & Cinsiyet & $\mathbf{N}$ & $\overline{\boldsymbol{X}}$ & SS & $\mathbf{t}$ & df & $\mathbf{p}$ \\
\hline \multirow{2}{*}{$\begin{array}{c}\begin{array}{c}\text { Öz düzenleme } \\
\text { becerisi }\end{array} \\
\end{array}$} & $\mathrm{K}_{1 \mathrm{z}}$ & 92 & 119,3 & 20,0 & \multirow{2}{*}{2,37} & \multirow{2}{*}{212} & \multirow{2}{*}{, $018^{*}$} \\
\hline & Erkek & 122 & 112,6 & 20,8 & & & \\
\hline \multirow{2}{*}{ Benlik Algısı } & $\mathrm{K} 1 \mathrm{Z}$ & 92 & 73,3 & 8,4 & \multirow{2}{*}{1,84} & \multirow{2}{*}{212} & \multirow{2}{*}{, 066} \\
\hline & Erkek & 122 & 71,1 & 8,6 & & & \\
\hline
\end{tabular}
" $p<.05$

Tablo 3'te okul öncesi dönem çocuklarının öz düzenleme becerileri cinsiyet değişkenine göre anlamlı farkl1l1k göstermektedir $(\mathrm{t}(2,37)=214 ; \mathrm{p}<.05)$. Ortalamalara bakıldığında kız çocukların erkek çocuklarına göre öz düzenleme becerileri daha yüksektir ( $\left.\overline{\mathrm{X}}_{\mathrm{k1z}}=119,3 ; \mathrm{ss}=20,0 ; \overline{\mathrm{X}}_{\text {erkek }}=112,6 ; \mathrm{ss}=20,8\right)$.

Okul öncesi dönem çocuklarının benlik algıları cinsiyet değişkenine göre anlamlı farklılık göstermemektedir.

Tablo 4. Okul Öncesi Dönem Çocuklarının Öz düzenleme Becerileri ve Benlik Algılarının Yaş Değişkenine Göre Farklılaşma Durumuna İlişkin Yapılan Bağımsız Gruplar t-Testi Sonuçları

\begin{tabular}{|c|c|c|c|c|c|c|c|}
\hline & Yaş & $\mathbf{N}$ & $\overline{\boldsymbol{X}}$ & ss & $\mathbf{t}$ & df & $\mathbf{p}$ \\
\hline \multirow{2}{*}{$\begin{array}{c}\text { Öz düzenleme } \\
\text { becerisi }\end{array}$} & $48-60$ & 105 & 111,0 & 18,82 & \multirow{2}{*}{$-3,18$} & \multirow{2}{*}{209,721} & \multirow{2}{*}{, $000^{* * *}$} \\
\hline & $61-72$ & 109 & 119,8 & 21,70 & & & \\
\hline \multirow{2}{*}{ Benlik Algısı } & $48-60$ & 105 & 71,7 & 8,57 & \multirow{2}{*}{,-62} & \multirow{2}{*}{212} & \multirow{2}{*}{,533 } \\
\hline & 61-72 & 109 & 72,4 & 8,67 & & & \\
\hline
\end{tabular}

Tablo 4'e göre okul öncesi dönem çocuklarının öz düzenleme becerileri yaş değişkenine göre anlamlı farklılık göstermektedir $(\mathrm{t}(-3,18)=214 ; \mathrm{p}<.001)$. Ortalamalara bakıldığında 61-72 aylık çocukların 4860 aylık çocuklara göre öz düzenleme becerileri daha yüksektir $\left(\bar{X}_{61-72}=119,8 ;\right.$ ss=21,70; $\bar{X}_{48 \text { - }}$ $\left.{ }_{60}=111,0 ; \mathrm{ss}=18,82\right)$.

Okul öncesi dönem çocuklarının benlik algıları yaş değişkenine göre anlamlı farklılık göstermemektedir.

Tablo 5. Okul Öncesi Dönem Çocuklarının Öz düzenleme Becerileri ve Benlik Algılarının Kardeş Sayısı Değişkenine Göre Farklılaşma Durumuna İlişkin Yapılan Tek Yönlü Varyans Analizi (ANOVA) Sonuçları

\begin{tabular}{|c|c|c|c|c|c|c|c|}
\hline & & & & Kardeş Sayısı & $\mathbf{N}$ & $\overline{\boldsymbol{X}}$ & Ss \\
\hline \multirow{3}{*}{$\begin{array}{c}\text { Öz Düzenleme } \\
\text { Becerisi }\end{array}$} & & & & Tek Çocuk & 73 & 113,4 & 17,59 \\
\hline & & & & 1 kardeş & 102 & 110,4 & 17,24 \\
\hline & & & & 2ve üstü kardeş & 39 & 109,0 & 16,31 \\
\hline \multirow{4}{*}{ Benlik Algısı } & & & & Tek Çocuk & 73 & 71,5 & 7,24 \\
\hline & & & & 1 kardeş & 102 & 72,6 & 7,51 \\
\hline & & & & 2ve üstü kardeş & 39 & 71,2 & 5,84 \\
\hline & Değişken & $\begin{array}{c}\text { Varyansın } \\
\text { Kaynağı }\end{array}$ & KT & SD & KO & $\mathbf{F}$ & $\mathbf{p}$ \\
\hline \multirow{3}{*}{$\begin{array}{c}\text { Öz Düzenleme } \\
\text { Becerisi }\end{array}$} & Kardes & Gruplararas1 & 617,826 & 2 & 308,913 & & \\
\hline & Savis! & Gruplariçi & 62494,286 & 211 & 296,181 & 1,043 & ,354 \\
\hline & & Toplam & 63112,112 & 213 & & & \\
\hline \multirow{3}{*}{ Benlik Algısı } & & Gruplararas1 & 86,216 & 2 & 43,108 & & \\
\hline & Karaeş & Gruplariçi & 10789,616 & 211 & 51,136 & ,843 & ,432 \\
\hline & & Toplam & 10875,832 & 213 & & & \\
\hline
\end{tabular}

Tablo 5'e bakıldığında, okul öncesi dönem çocuklarının öz düzenleme becerisi puan ortalamalarının $(\mathrm{F}=1,043 \mathrm{p}>.05)$ ve benlik algısı puan ortalamalarının $(\mathrm{F}=, 843 \mathrm{p}>.05)$ kardeş sayısı değişkenine göre anlamlı bir farklılık göstermediği görülmektedir. 
Tablo 6. Okul Öncesi Dönem Çocuklarının Öz düzenleme Becerileri ve Benlik Algılarının Anne Öğrenim Durumu Değişkenine Göre Farklılaşma Durumuna İlişkin Yapılan Tek Yönlü Varyans Analizi (ANOVA) Sonuçları

\begin{tabular}{|c|c|c|c|c|c|c|c|}
\hline & & & & $\begin{array}{c}\text { Anne Öğrenim } \\
\text { Durumu }\end{array}$ & $\mathbf{N}$ & $\overline{\boldsymbol{X}}$ & Ss \\
\hline$\ddot{\mathbf{O} z}$ & & & & İlkokul ve ortaokul & 41 & 109,37 & 15,58 \\
\hline Düzenleme & & & & Lise & 61 & 109,31 & 15,60 \\
\hline Becerisi & & & & Üniversite & 112 & 114,24 & 16,83 \\
\hline \multirow{4}{*}{ Benlik Algısı } & & & & İlkokul ve ortaokul & 41 & 68,22 & 5,97 \\
\hline & & & & Lise & 61 & 72,46 & 5,69 \\
\hline & & & & Üniversite & 112 & 72,34 & 7,38 \\
\hline & Değişken & $\begin{array}{c}\text { Varyansın } \\
\text { Kaynağı } \\
\end{array}$ & KT & SD & KO & $\mathbf{F}$ & $\mathbf{p}$ \\
\hline$\ddot{\mathbf{O} z}$ & Anne & Gruplararas1 & 1285,854 & 2 & 642,927 & & \\
\hline Düzenleme & Öğrenim & Gruplariçi & 55779,085 & 211 & 264,356 & 2,432 & ,090 \\
\hline Becerisi & Durumu & Toplam & 57064,939 & 213 & & & \\
\hline \multirow{3}{*}{ Benlik Algısı } & Anne & Gruplararas1 & 574,707 & 2 & 287,353 & & \\
\hline & Öğrenim & Gruplariçi & 9429,279 & 211 & 44,689 & 6,430 &, $002^{* *}$ \\
\hline & Durumu & Toplam & 10003,986 & 213 & & & \\
\hline
\end{tabular}

Tablo 6'da okul öncesi dönem çocuklarının öz düzenleme becerisi puan ortalamalarının $(\mathrm{F}=2,432$ p>.05) anne öğrenim durumu değişkenine göre anlamlı bir farklılık göstermediği görülmektedir. Benlik algısı puan ortalamalarının $(\mathrm{F}=6,430 \mathrm{p}<.01)$ ise anne öğrenim durumu değişkenine göre anlamlı farklılık gösterdiği görülmektedir. Yapılan homojenlik testi sonucunda; varyansların homojen dağılmadığı belirlenmiş, bu nedenle farklılıkların yönünü bulmak amacıyla Tamhane Testi uygulanmış ve sonuçları Tablo 7'de sunulmuştur.

Tablo 7. Okul Öncesi Dönem Çocuklarının Benlik Algılarının Anne Öğrenim Durumu Değişkenine Göre Farklılaşma Durumu ile İlgili Yapılan TamhaneTesti Sonuçları

\begin{tabular}{|c|c|c|c|c|}
\hline & I (Anne Öğrenim Durumu) & $\begin{array}{c}\text { Anne Öğrenim Durumu } \\
(\mathbf{J})\end{array}$ & $\mathbf{X}_{\mathrm{I}}-\mathbf{X}_{\mathrm{J}}$ & p \\
\hline \multirow{5}{*}{ Benlik Algısı } & İlkokul ve Ortaokul & $\begin{array}{l}2 \\
3\end{array}$ & $\begin{array}{l}-4,240 \\
-4,120\end{array}$ &, $002^{*}$ \\
\hline & \multirow{2}{*}{ Lise } & $\frac{3}{1}$ & $\frac{-4,120}{4,240}$ &, $002^{*}$ \\
\hline & & 3 &, 120 & ,999 \\
\hline & \multirow{2}{*}{ Üniversite } & 1 & 4,120 &, $002^{*}$ \\
\hline & & 2 &,- 120 & 999 \\
\hline
\end{tabular}

Tablo 7'ye göre Benlik Algıları puan ortalamaları anne öğrenim durumu değişkenine göre incelendiğinde; anne öğrenim durumu ilkokul ve ortaokul olan çocukların benlik algısı puan ortalamaları, anne öğrenim durumu lise ve üniversite olan çocuklardan düşük bulunmuştur. Diğer gruplar arasında anlamlı farklılığa rastlanmamıştır. 
Tablo 8. Okul Öncesi Dönem Çocuklarının Öz düzenleme Becerileri ve Benlik Algılarının Baba Öğrenim Durumu Değişkenine Göre Farklılaşma Durumuna İlişkin Yapılan Tek Yönlü Varyans Analizi (ANOVA) Sonuçları

\begin{tabular}{|c|c|c|c|c|c|c|c|}
\hline & & & & $\begin{array}{c}\text { Baba Öğrenim } \\
\text { Durumu }\end{array}$ & $\mathbf{N}$ & $\overline{\boldsymbol{X}}$ & Ss \\
\hline & & & & İlkokul ve & 40 & 110,35 & 16,40 \\
\hline & & & & ortaokul & 62 & 112,60 & 15,45 \\
\hline Düzenleme & & & & Lise & 112 & 112,07 & 16,94 \\
\hline & & & & Üniversite & & & \\
\hline \multirow{5}{*}{ Benlik Algısı } & & & & İlkokul ve & 40 & 68,98 & 6,68 \\
\hline & & & & ortaokul & 62 & 72,06 & 6,25 \\
\hline & & & & Lise & 112 & 72,25 & 7,06 \\
\hline & & & & Üniversite & & & \\
\hline & Değişken & $\begin{array}{c}\text { Varyansın } \\
\text { Kaynağı }\end{array}$ & KT & SD & KO & $\mathbf{F}$ & $\mathbf{p}$ \\
\hline$\ddot{\mathbf{O} z}$ & Baba & Gruplararası & 129,491 & 2 & 64,746 & & \\
\hline Düzenleme & Öğrenim & Gruplariçi & 56935,448 & 211 & 269,836 & 240 &, 787 \\
\hline Becerisi & Durumu & Toplam & 57064,939 & 213 & & & \\
\hline \multirow{3}{*}{ Benlik Algısı } & Baba & Gruplararası & 336,269 & 2 & 168,135 & & \\
\hline & Öğrenim & Gruplariçi & 9667,717 & 211 & 45,819 & 3,670 &, $027^{*}$ \\
\hline & Durumu & Toplam & 1003,986 & 213 & & & \\
\hline
\end{tabular}

Tablo 8'e göre okul öncesi dönem çocuklarının öz düzenleme becerisi puan ortalamalarının $(\mathrm{F}=, 240$ p>.05) baba öğrenim durumu değişkenine göre anlamlı bir farklılık göstermediği görülmektedir. Benlik algısı puan ortalamalarının $(\mathrm{F}=6,430 \mathrm{p}<.05)$ ise baba öğrenim durumu değişkenine göre anlamlı farklılık gösterdiği görülmektedir. Yapılan homojenlik testi sonucunda; varyansların homojen dağıldığı belirlenmiş, bu nedenle farklılıkların yönünü bulmak amacıyla Scheffe Testi uygulanmış ve sonuçları Tablo 9'da sunulmuştur.

Tablo 9. Okul Öncesi Dönem Çocuklarının Benlik Algılarının Baba Öğrenim Durumu Değişkenine Göre Farklılaşma Durumu ile İlgili Yapılan Scheffe Testi Sonuçları

\begin{tabular}{lcrcc}
\hline & $\mathbf{I}($ Baba Öğrenim Durumu) & Baba Öğrenim Durumu (J) & $\mathbf{X}_{\mathbf{I}}-\mathbf{X}_{\mathbf{J}}$ & $\mathbf{p}$ \\
\hline \multirow{3}{*}{ Benlik Algısı } & \multirow{2}{*}{ İlkokul ve Ortaokul } & 2 & $-3,090$ &, 082 \\
& & 3 & $-3,275$ &, $034^{*}$ \\
\cline { 2 - 6 } & \multirow{2}{*}{ Lise } & 1 & 3,090 &, 082 \\
& & 3 &,- 185 &, 985 \\
\cline { 2 - 6 } & \multirow{2}{*}{ Üniversite } & 1 & 3,275 &, $034^{*}$ \\
& & 2 &, 185 &, 985 \\
\hline${ }^{*} p<.05$ & & & &
\end{tabular}

Tablo 9'da Benlik Algıları puan ortalamaları baba öğrenim durumu değişkenine göre incelendiğinde; baba ögrenim durumu ilkokul ve ortaokul düzeyinde olan çocukların benlik algısı puan ortalamaları, baba öğrenim durumu üniversite olan çocuklardan düşük bulunmuştur. Diğer gruplar arasında anlamlı farklılığa rastlanmamıştır. 
Tablo 10. Okul Öncesi Dönem Çocuklarının Öz düzenleme Becerileri ve Benlik Algılarının Okul Öncesi Eğitim Kurumuna Devam Etme Süresi Değişkenine Göre Farklılaşma Durumuna İlişkin Yapılan Tek Yönlü Varyans Analizi (ANOVA) Sonuçları

\begin{tabular}{|c|c|c|c|c|c|c|c|}
\hline & & & & $\begin{array}{c}\text { Devam } \\
\text { Süresi }\end{array}$ & $\mathbf{N}$ & $\bar{X}$ & Ss \\
\hline Öz & & & & 1 & 91 & 110,2 & 20,07 \\
\hline Düzenleme & & & & 2 & 87 & 118,0 & 22,41 \\
\hline Becerisi & & & & 3 & 36 & 129,4 & 15,61 \\
\hline \multirow{4}{*}{ Benlik Algısı } & & & & 1 & 91 & 70,8 & 8,24 \\
\hline & & & & 2 & 87 & 73,1 & 9,33 \\
\hline & & & & 3 & 36 & 76,9 & 8,72 \\
\hline & Değişken & $\begin{array}{c}\text { Varyansın } \\
\text { Kaynağı }\end{array}$ & KT & SD & KO & $\mathbf{F}$ & $\mathbf{p}$ \\
\hline \multirow{3}{*}{$\begin{array}{c}\ddot{O} z \\
\text { Düzenleme } \\
\text { Becerisi }\end{array}$} & \multirow{3}{*}{$\begin{array}{l}\text { Devam } \\
\text { Süresi }\end{array}$} & Gruplararası & 9869,418 & 2 & 4934,709 & & \\
\hline & & Gruplariçi & 87999,591 & 211 & 417,060 & 11,832 &, $000^{* * *}$ \\
\hline & & Toplam & 97869,009 & 213 & & & \\
\hline \multirow{3}{*}{ Benlik Algısı } & \multirow{3}{*}{$\begin{array}{l}\text { Devam } \\
\text { Süresi }\end{array}$} & Gruplararas1 & 994,371 & 2 & 497,186 & & \\
\hline & & Gruplariçi & 16273,386 & 211 & 77,125 & 6,446 &, $002^{* *}$ \\
\hline & & Toplam & 17267,757 & 213 & & & \\
\hline
\end{tabular}

Tablo 10'da okul öncesi dönem çocuklarının öz düzenleme becerisi puan ortalamalarının ( $\mathrm{F}=11,832$ $\mathrm{p}<.05)$ ve benlik algısı puan ortalamalarının $(\mathrm{F}=6,446 \mathrm{p}<.05)$ okul öncesi eğitim kurumuna devam etme süresi değişkenine göre anlamlı farklılık gösterdiği görülmektedir. Yapılan homojenlik testi sonucunda; varyansların homojen dağıldığı belirlenmiş, bu nedenle farklılıkların yönünü bulmak amacıyla Scheffe Testi uygulanmış ve sonuçları Tablo 10 ve Tablo 11'de sunulmuştur.

Tablo 11. Okul Öncesi Dönem Çocuklarının Öz Düzenleme Becerilerinin Okul Öncesi Eğitim Kurumuna Devam Etme Süresi Değişkenine Göre Farklılaşma Durumu ile İlgili Yapılan Scheffe Testi Sonuçları

\begin{tabular}{|c|c|c|c|c|}
\hline & I ( Devam etme süresi ) & Devam etme süresi $(\mathrm{J})$ & $\mathbf{X}_{\mathbf{I}}-\mathbf{X}_{\mathrm{J}}$ & $\mathbf{p}$ \\
\hline \multirow{6}{*}{$\begin{array}{l}\text { Öz Düzenleme } \\
\text { Becerisi }\end{array}$} & \multirow[b]{2}{*}{1} & 2 & $-7,860$ &, $044^{*}$ \\
\hline & & 3 & $-19,263$ &, $000^{* * *}$ \\
\hline & \multirow{2}{*}{2} & 1 & 7,860 &, $044^{*}$ \\
\hline & & 3 & $-11,403$ &, $005^{* *}$ \\
\hline & \multirow[b]{2}{*}{3} & 1 & 19,263 &, $000^{* * * *}$ \\
\hline & & 2 & 11,403 &, $005^{* *}$ \\
\hline
\end{tabular}

Tablo 11'e göre, Öz Düzenleme Becerileri puan ortalamaları okul öncesi eğitim kurumuna devam etme değişkenine göre incelendiğinde; okul öncesi eğitim kurumuna 1 yll devam eden çocuklar ile 2 yıl devam eden çocuklar arasında, 2 yıl devam eden çocuklar lehine; yine 1 yıl devam eden çocuklar ile 3 yıl devam eden çocuklar arasında, 3 yıl devam eden çocuklar lehine anlamlı farklılığa rastlanmıştır. Ayrıca okul öncesi eğitim kurumuna 2 yıl devam eden çocuklar ile 3 yıl devam eden çocuklar arasında, 3 yıl devam eden çocuklar lehine anlamlı farklılığa rastlanmıştır.

Tablo 12. Okul Öncesi Dönem Çocuklarının Benlik Algılarının Okul Öncesi Eğitim Kurumuna Devam Etme Süresi Değişkenine Göre Farklılaşma Durumu ile İlgili Yapılan Scheffe Testi Sonuçları

\begin{tabular}{|c|c|c|c|c|}
\hline & I ( Devam etme süresi ) & Devam etme süresi $(\mathbf{J})$ & $\mathbf{X}_{\mathbf{I}}-\mathbf{X}_{\mathrm{J}}$ & $\mathbf{p}$ \\
\hline \multirow{6}{*}{ Benlik Algısı } & \multirow{2}{*}{1} & 2 & $-2,382$ & ,205 \\
\hline & & 3 & $-6,142$ &, $002^{* *}$ \\
\hline & \multirow{2}{*}{2} & 1 & 2,382 & ,205 \\
\hline & & 3 & $-3,761$ & , 106 \\
\hline & \multirow{2}{*}{3} & 1 & 6,142 &, $002^{* *}$ \\
\hline & & 2 & 3,761 & , 106 \\
\hline
\end{tabular}


Tablo 12'de görüldüğü göre, Benlik Algıları puan ortalamaları okul öncesi eğitim kurumuna devam etme değişkenine göre incelendiğinde; okul öncesi eğitim kurumuna 1 y1l devam eden çocuklar ile 3 yıl devam eden çocuklar arasında, 3 yıl devam eden çocuklar lehine anlamlı farklılaşma bulunmaktadır. Diğer süreler arasında anlamlı farklılığa rastlanmamıştır.

\section{SONUÇ VE TARTIŞMA}

Okul öncesi dönem çocuklarının öz düzenleme becerileri ile ilgili puan ortalamaları 111,9 olarak bulunmuştur. Öz Düzenleme Becerileri Ölçeğinden alınabilecek en düşük puanın 33, en yüksek puanın ise 165 olduğu göz önüne alındığında çocukların söz konusu becerilerinin kısmen yüksek düzeyde olduğu yorumu yapılabilir. Bu sonuca benzer olarak; Fındık-Tanrıbuyurdu (2012), Ertürk-Kara ve Gönen (2015), Aksoy ve Tozduman-Yaralı (2017) araştırmalarında çocukların öz düzenleme becerilerinde yüksek puanlar aldıklarını belirtmişlerdir.

Okul öncesi dönem çocuklarının benlik algısı puan ortalamaları 71,5 olarak bulunmuştur. DeMoulin Çocuklar İçin Benlik Algısı Ölçeğinden alınabilecek en düşük puanın 28, en yüksek puanın ise 84 olduğu göz önünde bulundurulduğunda çocukların benlik algısı düzeylerinin de yüksek olduğu sonucuna ulaşılabilir. Araştırma sonucuna benzer olarak Evirgen-Geniş ve Gözün-Kahraman (2018); okul öncesi dönem çocuklarında bağlanma ve benlik algısı arasındaki ilişkiyi inceledikleri araştırma sonucunda, çocukların genel benlik algısı puan ortalamalarının yüksek düzeyde olduğunu belirtmişlerdir.

Okul öncesi dönem çocuklarının öz düzenleme becerileri ile benlik algıları arasında orta düzeyde ve pozitif yönde anlamlı bir ilişki bulunmuştur. Bu sonuca göre; çocukların öz düzenleme becerileri arttıkça benlik algıları da artmaktadır. Çocuğun bulunduğu gelişim döneminde ve daha sonraki gelişim dönemlerinde kişilik gelişimini sağliklı bir şekilde sürdürebilmesi için kendine ilişkin duygu ve düşünceleri yani benlik algısının önemli bir faktör olduğu düşünülmektedir (Yukay-Yüksel ve Yıldırım-Kurtuluş, 2016). Okul öncesi dönemde temelleri atılan öz düzenleme becerilerinin geliştirilmesi, kazanılması da çocuğun kendisiyle ilgili duygu ve düşüncelerini olumlu yönde etkileyerek benlik algısı düzeyini de artırabilir. Duygu, düşünce ve davranışlarını kontrol etme, denetleme, düzenleme gibi kazanımlar çocuğun kendisine yönelik olumlu tutum geliştirmesini de sağlayabilir.

Okul öncesi dönem çocuklarının öz düzenleme becerileri ile cinsiyet değişkenine ait sonuçlar incelendiğinde, kızların öz düzenleme becerileri erkeklerden daha yüksek düzeyde bulunmuştur. Yapılan bazı çalışmalarda çocukların öz düzenleme becerilerinin cinsiyete göre anlamlı farklılık göstermediği sonucuna ulaşılmıştır (Jahromi ve Stifter, 2008; Ertürk-Kara ve Gönen, 2015; ŞepitciSarıbaş ve Gültekin-Akduman, 2019; Mercan, 2019). Bu sonuçlar araştırma sonucuyla benzerlik göstermemektedir. Kız çocukların öz düzenleme becerilerinin erkeklere göre daha yüksek olduğunu belirten çalışmalar da literatürde mevcuttur (Matthews, Ponitz ve Morrison, 2009; Kurbet, 2010; Özbey, 2018; Eroğlu, 2018; Karakurt, 2019). Kız çocuklarının öz düzenleme becerilerinin erkek çocuklardan yüksek çıkmasının nedenini kültürel faktörler ve çocuk yetiştirme tutumlarından kaynaklandığını belirten çalışmalar bulunmaktadır (Tutkun, Tezel-Şahin ve Işıktekiner, 2016; Eroğlu, 2018). Aksoy ve Tozduman-Yaralı, (2017) ise erken yaştan itibaren erkeklerin kızlardan daha hareketli ve atak olduklarını, engellendiklerinde daha huzursuz olma ve dürtüsel hareket etme eğiliminde olduklarını bu nedenle kız çocuklarının erkek çocuklara göre öz düzenleme becerilerinin yüksek olduğunu aktarmıştır. Alan yazın değerlendirildiğinde; cinsiyet değişkeninin öz düzenleme becerileri üzerinde farklılığa neden olup olmamasının tartışma konusu olduğu ve cinsiyetin tek başına öz düzenleme becerilerini açıklamada yetersiz kalabileceği düşünülebilir. Cinsiyetin yanında aile ve öğretmen tutumları, kültürel faktörler, yaşanılan çevrenin özellikleri de öz düzenleme becerileri üzerinde etkili olabilir. Bu nedenle öz düzenlemenin cinsiyet değişkeni ile aile ve öğretmen tutumları ile, farklı kültürel özelliklerin bulunduğu bölgeler ile değerlendirildiği çalışmaların yapılması önerilmektedir.

Çocukların benlik algıları cinsiyet değişkenine farklılık göstermemiştir. Karaca ve Aral (2017), araştırmalarının sonucunda çocukların benlik algılarının cinsiyete göre farklılık göstermediğini belirtmişlerdir. Yine Türkmen ve Özbey (2018), araştırmalarında çocukların benlik algılarının cinsiyet 
değişkenine göre farklılık göstermediğini belirtmiştir. Bu çalışmalar araştırma sonucu ile benzerlik göstermektedir. Yapılan bazı çalışmalarda ise kız çocuklarının benlik algılarının ve bazı alt boyutlarının erkek çocukların benlik algılarından yüksek bulunduğu görülmektedir (Çelik, Tuğrul ve Yalçın, 2002; Bencik, 2006; Sarıca, 2010; Zembat, Koçyiğit, Akşin-Yavuz ve Tunçeli, 2018). Erkek çocuklarının benlik algılarının kız çocuklarından yüksek olduğu sonucuna ulaşılan çalışmalar da literatürde mevcuttur (Polat ve Akşin, 2015; Akşin-Yavuz, Güven, Bayındır, Sezer ve Yılmaz, 2016). Alan yazında görülen farklılıklar, okul öncesi dönemde benlik algısının cinsiyete göre farklılaşıp farklılaşmadığı ya da farklılaşma var ise kızlar lehine mi erkekler lehine mi olduğu konusunda bize net bir fikir vermemektedir. Bu nedenle yine okul öncesi dönemde benlik algısının cinsiyete göre değerlendirildiği çalışmalara ihtiyaç duyulmaktadır.

Okul öncesi dönem çocuklarının öz düzenleme becerileri ile yaş değişkenine ait sonuçlara bakıldığında çocukların yaşları arttıkça öz düzenleme becerilerinin de arttı̆̆ görülmektedir. Fındık-Tanrıbuyurdu (2012), araştırmasının sonucunda 5 yaş grubu çocukların öz düzenleme becerilerinin 4 yaş grubu çocuklardan yüksek olduğunu belirtmiştir. Tutkun, Tezel-Şahin ve Işıktekiner (2016) tarafından yapılan araştırmada, 4 yaş grubu çocuklarının öz düzenleme becerilerinin 5 yaş grubu çocukların öz düzenleme becerilerinden düşük olduğu sonucuna ulaşılmıştır. Yine Şepitci-Sarıbaş ve Gültekin-Akduman (2019) yaptıkları araştırmada, 48-60 aylık çocukların öz düzenleme becerilerinin 60-72 aylık çocuklardan düşük olduğunu belirtmişlerdir. Yapılan bu çalışmalar araştırma sonucunu destekler niteliktedir. Yaşa göre öz düzenleme becerisinin farklılık göstermediği çalışmalar da literatürde mevcuttur (Ertürk-Kara ve Gönen, 2015; Özbey, 2018). Mercan (2019), ise araştırmasının sonunda 5 yaş grubu çocukların öz düzenleme becerilerinin 6 yaş grubu çocukların öz düzenleme becerilerinden yüksek olduğunu belirtmiştir. Yaş ile birlikte tüm gelişim alanlarında görülen ilerlemelerin, öz düzenleme becerisinin de gelişimine katkıda bulunacağı düşünülmektedir. Nitekim Skibbe, McDonald Connor, Morrison ve Jewkes (2011), yaptıkları araştırmanın sonucunda öz düzenlemenin yaşla birlikte geliştiğini belirtmiş ve bu durumun nedenini; yaşla birlikte gelişimin her alanında bir ilerlemenin görülmesi ve bu ilerlemenin de öz düzenleme becerisini olumlu yönde etkileyeceği şeklinde açıklamışlardır.

Çocukların benlik algıları yaş değişkenine göre farklılık göstermemiştir. Karaca ve Aral (2017), araştırmalarında 48-60 aylık çocukların benlik algılarının 60-72 aylık çocukların benlik algılarından yüksek olduğu sonucuna ulaşmışlardır. Bu sonuç araştırma sonucu ile benzerlik göstermemektedir. Öz düzenleme becerileri ile benlik algısının birbiriyle ilişkili olabileceği düşünüldüğünde, öz düzenleme becerilerinde yaşa bağlı olarak farklılığın görülmesi ancak benlik algısında anlamlı bir farklılığın çıkması şaşırtıcı bir sonuç olarak değerlendirilebilir. Benlik algısının farklı değişkenlerden de etkileneceği düşünülebileceği gibi bu araştırmaya dahil olan çocukların öz düzenleme becerileri kazanmış olsalar da geliştirmiş oldukları benlik algılarının henüz yaş aralığına göre ayırt edici bir farklılık kazanmadığı yönünde yorum yapılabilir.

Okul öncesi dönem çocuklarının öz düzenleme becerileri ve benlik algıları kardeş sayısı değişkenine göre farklılık göstermemiştir. Mercan (2019), yaptığı araştırmada kardeş sayısı değişkenine göre çocukların öz düzenleme becerilerinin farklılık göstermediğini belirtmiştir. Bu sonuç araştırma sonucunu destekler niteliktedir. Dağgül'ün (2016) yüksek lisans bitirme tezi kapsamında yaptığ1 araştırmasında, ailede bulunan çocuk sayısı ile öz düzenleme becerileri açısından istatistiksel olarak anlamlı düzeyde olmasa da çocuk sayısı azaldıkça öz düzenleme becerileri düzeyinin yükselmesi yönünde bir fark olduğu belirlenmiştir. Araştırma sonucunda tek çocuk olanların belirgin bir biçimde daha yüksek öz düzenleme becerilerine sahip oldukları görülmüşsür. Benzer şekilde Tutkun, TezelŞahin ve Işıktekiner (2016), araştırmalarında ailedeki kardeş sayısı arttıkça öz düzenleme becerilerinin azaldığ 1 , tek çocuk olanların öz düzenleme becerilerinin iki ve daha fazla kardeşe sahip çocuklardan yüksek olduğu sonucuna ulaşmışlardır. Literatürde kardeş sayısının yanı sıra doğum sırası değişkenine yer verilmiştir. Doğum sırası arttıkça kardeş sayısı artacağı için iki değişkene ait sonuçların da birbiriyle ilişkili olabileceği düşünülebilir. Fındık-Tanrıbuyurdu'nun (2012) çalışmasında öz düzenleme becerisi ile çocukların doğum sırasına ilişkin yaptığı analizler sonucunda, doğum sırasının çocukların öz düzenleme becerileri üzerinde etkili olmadığı saptanmıştır. Söz konusu araştırma sonucu, bu araştırma sonucuyla birbirini desteklemektedir. 
Kardeş sayısı değişkeninin doğum sırası değişkeni ile bağlantılı olarak düşündüğümüzde Karaca ve Aral (2017)'ın yapmış oldukları çalışmada da çocukların doğum sırasına göre benlik algılarının farklılık göstermediği sonucuna ulaşılmıştır. Bu sonuç araştırma sonucu ile benzerlik göstermektedir. Türkmen ve Özbey (2018), ise araştırmalarının sonucunda kardeş sayısı değişkenine göre çocukların benlik algılarının tek çocuklar lehine olduğunu belirtmişlerdir.

Okul öncesi dönem çocuklarının öz düzenleme becerileri anne ve babalarının öğrenim durumuna göre farklılık göstermemiştir. Ertürk Kara ve Gönen'in (2015) yaptıkları çalışmada, çocukların duygu düzenleme becerilerinin; annelerinin ve babalarının öğrenim durumlarına bağlı olarak farklılaştığını ve annelerinin ve babalarının öğrenim durumu yüksek olan çocukların dikkat/dürtü kontrollerinin anlamlı düzeyde yüksek olduğunu belirtmişlerdir. Ivrendi'nin (2011) yaptığı bir çalışmada anne öğrenim durumunun çocuğun davranış düzenleme becerisini belirgin ölçüde etkilediğini belirtmiştir. Kurbet'in (2010) çalışmasında ise anne öğrenim durumlarının çocuğun duygusal düzenleme becerisi ile ilişkili olmadığı ortaya çıkmıştır. Anne ve baba öğrenim durumunun öz düzenleme becerisinde tek başına yeterli olmayacağı düşünülmektedir. Öğrenim durumunun yanında ebeveyn tutumları da çocuğun öz düzenleme becerisini etkileyebilir.

Anne ve baba öğrenim düzeyi arttıkça çocukların benlik algılarının da arttığı sonucuna ulaşılmıştır. Duygusal gelişimin sağlıklı olabilmesinde anahtar rolü, anne-baba oynamaktadır. Çocukta kişiliğin oluşmasında ebeveynler çok önemli bir role sahiptir (Evirgen-Geniş ve Gözün-Kahraman, 2018). Erken çocukluk dönemindeki anne-baba etkileşimi, benlik algıSı aracılığıyla etkisini çocuğun ileriki yaşantısında duygusal, davranışsal, bilişsel alanlarına taşımaktadır (Sümer ve Şendağ, 2009). Anne babaların öğrenim düzeyleri arttıkça çocuklarının duygusal ihtiyaçlarına yönelik farkındalıklarının da artacağı düşünülebilir. Bu nedenle ele alınan değişken, çocukların olumlu benlik kazanmalarında etkili olabilir.

Okul öncesi dönem çocuklarının öz düzenleme becerileri ve benlik algıları ile okul öncesi eğitim kurumuna devam etme süresi değişkenine ait sonuçlar incelendiğinde, eğitim kurumuna daha uzun süre devam eden çocukların öz düzenleme becerilerinin ve benlik algılarının daha yüksek olduğu görülmüştür. Ekinci-Vural (2012) okul öncesi eğitim alan çocukların öz düzenleme becerilerinin daha yüksek olduğunu belirlemiştir. Bu nedenle eğitim ortamı, eğitim programı ve öğretim yaklaşımlarının çocuklarda öz düzenlemeyi destekleyici olarak düzenlenmesi gerekmektedir. Eğitim ortamında öz düzenleme çocuğun öğrenmesinde aktif olmasını, kendi öğrenmesini kendisinin oluşturmasını sağlamaktadır. Sınıf ortamının, eğitim yaklaşımlarının ve öğretmen çocuk etkileşiminin çocukların öz düzenleme becerilerini etkilediği görülmektedir (Aydın ve Ulutaş, 2017).

Çocukların benlik algılarının okul öncesi eğitim kurumuna devam etme süresi değişkenine göre incelendiği çalışmalarda, okul öncesi eğitim kurumuna devam etme süresi arttıkça çocukların benlik algılarının arttığı gözlemlenmiştir (Türkmen ve Özbey, 2018; Yaralı, 2015; Sarıca, 2010). Yapılan çalışmalar araştırma sonucunu destekler niteliktedir. Okul öncesi eğitimin çocuğun tüm gelişim alanlarını desteklediği düşünüldügünde; çocukların benlik algılarını da desteklemesi beklenen bir sonuçtur. Bu nedenle okul öncesi eğitim kurumuna devam etme süresinin artması, çocukların benlik algılarını destekleyebilir.

Okul öncesi dönem çocuklarının öz düzenleme becerileri ile benlik algılarının incelendiği araştırma sonuçlarına göre;

- Okul öncesi dönem çocuklarının öz düzenleme becerileri ile benlik algıları arasında orta düzeyde ve pozitif yönde anlamlı bir ilişki bulunmuştur.

- Cinsiyet değişkenine göre öz düzenleme becerileri açısından, kızların öz düzenleme becerileri erkeklerden daha yüksek düzeyde bulunmuştur. Benlik algıları ise cinsiyete göre farklılaşmamaktadır.

- Yaş, değişkenine göre çocukların öz düzenleme becerisi farklılık göstermektedir. Çocukların yaşları arttıkça öz düzenleme becerilerinin arttığı sonucuna ulaşılmıştır. Çocukların benlik algıları yaş değişkenine göre farklılık göstermemiştir. 
- Kardeş sayısı değişkenine göre çocukların öz düzenleme becerileri ve benlik algıları farklılık göstermemiştir.

- Okul öncesi dönem çocuklarının öz düzenleme becerileri anne ve babalarının öğrenim durumuna göre farklılık göstermezken, benlik algılarının farklılık gösterdiği sonucuna ulaşı1mıştır.

- Okul öncesi eğitim kurumuna devam etme süresi değişkenine göre çocukların öz düzenleme

\section{Öneriler} becerileri ve benlik algıları farklılık göstermiştir.

- Araştırma sonuçları incelendiğinde çocukların cinsiyeti değişkenine ait sonuçların literatürde de farklılık gösterdiği görülmektedir. Bu nedenle özellikle bu değişkenin ele alındığı çalışmalar yapılması önerilebilir. Ayrıca bu araştırmada zaman sınırlaması nedeniyle sosyoekonomik düzey, çocukların devam ettiği eğitim kurumunun türü gibi değişkenlere de yer verilememiştir. Bu nedenle bir sonraki araştırmalarda söz konusu değişkenler de ele alınarak daha ayrıntılı araştırmalar planlanabilir.

- Olumlu bir benlik algısı geliştirilmesinde öz düzenleme becerilerinin kazanılmasının da etkili olduğu sonucuna ulaşıldığından ailelere ve öğretmenlere; çocuklara kendi duygu, düşünce ve davranışlarını değerlendirme, denetleme ve düzenleme imkanı sunacak daha fazla firsatlar sunmaları, çocuğun bireysel farkındalığına katkı sağlayacak oyun ve etkinliklere daha çok yer vermeleri önerilebilir.

\section{KAYNAKÇA}

Akawi, R.L. (2011). An investigation into the relationship between self- regulation skills and academic readiness in head start children. Unpublished doctoral thesis, State University of New York, USA.

Aksoy, A.B.ve Tozduman-Yaralı, K. (2017). Çocukların öz düzenleme becerileri ile oyun becerilerinin cinsiyete göre incelenmesi. Trakya Üniversitesi Ĕ̈itim Fakültesi Dergisi, 7(2), 442-455.

Akşin-Yavuz, E., Güven, G., Bayındır, D., Sezer, T. ve Yılmaz, E. (2016). Annelerin çocuğunu kabul düzeyi ile çocukların benlik algıları arasındaki ilişkinin incelenmesi. Abant İzzet Baysal Üniversitesi Ĕgitim Fakültesi Dergisi, 16(3), 1065-1081.

Aydın, F. ve Ulutaş, İ. (2017). Okul öncesi çocuklarda öz düzenleme becerilerinin gelişimi. Aksaray Üniversitesi Sosyal Bilimler Enstitüsü Dergisi, 1(2), 36-45.

Balc1, A. (2001). Sosyal bilimlerde araştırma yöntem, teknik ve ilkeler. Ankara: PegemA Yayınc1lık.

Bayındır, D. ve Ural, O. (2016). Development of the Self-Regulation Skills Scale. International Online Journal of Educational Sciences. 8(4), 119-132.

Bee, H., ve Boyd, D. (2009). Çocuk gelişim psikolojisi. (Çev. O.Gündüz). İstanbul: Kaknüs Yayınları.

Bencik, S. (2006). Üstün yetenekli çocuklarda mükemmeliyetçilik ve benlik algısı arasındaki ilişsinin incelenmesi. Yayımlanmamış yüksek lisans tezi, Hacettepe Üniversitesi Sağlık Bilimleri Enstitüsü, Ankara.

Bodrova, E., Germeroth, C. \& Leong, D.J. (2013). Play and Self-Regulation: Lessons from Vygotsky. American Journal of Play, 6, 111-23.

Bondurant, L.M. (2010). The roots of academic underachievement: Prediction from early difficulties with self-regulation. Unpublished doctoral thesis, University of Texas, USA.

Bosacki, L.S. (2007). Children's understandings of emotions and self: are there gender differences? Journal Research in Childhood Education, 22(2), 155-172.

Büyüköztürk, Ş., Kılıç Çakmak, E., Akgün, Ö.E., Karadeniz, Ş. ve Demirel, F. (2016). Bilimsel araştırma yöntemleri. Ankara: Pegem Akademi Yayıncılık. 
Çelik, E., Tuğrul, B. ve Yalçın, S. S. (2002). Dört altı yaşlar arasındaki anaokulu çocuklarının duygusal yüz ifadesiyle kendilerini, anne-babalarını ve öğretmenlerini algılaması. Hacettepe Üniversitesi Ĕ̈itim Fakültesi Dergisi, 22, 29-39.

Dağgül, H.C. (2016). Okul öncesi dönem çocuklarının öz düzenleme becerileri ile ebeveynlerin çocuk yetiştirme stilleri arasındaki ilişkinin incelenmesi. Yayımlanmamış yüksek lisans tezi, Doğu Akdeniz Üniversitesi, Kuzey Kıbrıs Türk Cumhuriyeti.

Demoulin, D.F. (1999). A personalized development of self concept for beginning readers. Journal of Education, 20(1), 14

Dündar, B. (2010). Okul öncesi dönem 6 yaşs çocuklarının benlik algıları ile bilişsel performansları arasındaki ilişsi. (Yayımlanmamış yüksek lisans tezi). İstanbul Üniversitesi Sosyal Bilimler Enstitüsü, İstanbul.

Ekinci-Vural, D. (2012). Okul öncesi eğitimin ilköğretime etkisinin aile katılımı ve çeşitli değişkenler açısından incelenmesi. Yayımlanmamış doktora tezi, Dokuz Eylül Üniversitesi/Sosyal Bilimler Enstitüsü, İzmir.

Eroğlu, E. (2018). Çocukların öz düzenleme becerileri ile ebeveynlerin olumsuz disiplin uygulamaları arasındaki ilişki. Yayımlanmamış yüksek lisans tezi, Çukurova Üniversitesi Sosyal Bilimler Enstitüsü, Adana.

Ertürk-Kara, H.G. ve Gönen, M. (2015). Okul öncesi dönemdeki çocukların öz düzenleme becerisinin çeşitli değişkenler açısından incelenmesi. Eğitimde Kuram ve Uygulama. 11 (4), 1224-1239.

Evirgen-Geniş, N. ve Gözün-Kahraman, Ö. (2018). Okul öncesi dönem çocuklarında bağlanma ve benlik algısı arasındaki ilişkinin incelenmesi. Hitit Üniversitesi Sosyal Bilimler Enstitüsü Dergisi. (3), 2446-2454.

Fındık-Tanrıbuyurdu, E. (2012). Okul Öncesi Öz Düzenleme Ölçeği Geçerlik ve Güvenirlik Çalışması. Yayımlanmamış yüksek lisans tezi, Hacettepe Üniversitesi Sosyal Bilimler Enstitüsü, Ankara.

Gizir, Z. (2002). Anaokuluna devam eden dört-beş çocuklarında sosyal davranışların gelişimi ile benlik saygısı arasındaki ilişkinin incelenmesi. Yayımlanmamış yüksek lisans tezi, Ankara Üniversitesi Fen Bilimleri Enstitüsü, Ankara.

Grolnick, W.S. \& Farkas M. (2002). Parenting and the Development of Children's Self Regulation. M.Borstein (Eds). Handbook of Parenting Practical Issues in Parenting. (pp.89-110) London: Lawrence Erlbaum Associates, Publishers.

Ivrendi, A. (2011). Influence of self-regulation on the development of children's number sense. Early Childhood Education Journal, 39(4), 239-247.

Jahromi, L.B. \& Stifter, C.A. (2008). Individual differences in preschoolers'self regulation and theory of mind. Merrill-Palmer Quarterly. 54(1), 125-150.

Karaca, N.H. ve Aral, N. (2017). Investigation of the effect of various demographical characteristics on pre-schoolers' self concept. Eurasian Journal of Educational Research, 71, 97-118.

Karakurt, Ç. (2019). Okul öncesi eğitime devam eden 48-72 aylık çocukların öz düzenleme becerileri ile dil becerileri arasındaki ilişkinin incelenmesi. Yayınlanmamış yüksek lisans tezi, İstanbul Üniversitesi-Cerrahpaşa Lisansüstü Eğitim Enstitüsü, İstanbul.

Kartal, H. (2007). Erken çocukluk eğitimi programlarından Anne-Çocuk Eğitimi Programı'nın altı yaş grubundaki çocukların bilişsel gelişimlerine etkisi. Illköğretim Online 6(2), 234-248.

Kochanska, G., Coy, K.C. \& Murray, K.T. (2001). The development of self-regulation in the first four years of life. Child Development, 72(4), 1091-1111.

Köklü, N., Büyüköztürk Ş. ve Bökeoğlu, Ö.Ç. (2006). Sosyal bilimler için istatistik. Ankara: Pegem-A Yayınc1lk. 
Kurbet, H. (2010). Anaokuluna devam eden 5-6 yaş çocuklarının duygusal düzenleme becerileri ile annelerinin empatik eğilim ve tutumlarının incelenmesi. Yayınlanmamış yüksek lisans tezi, Gazi Üniversitesi Eğitim Bilimleri Enstitüsü, Ankara.

Kuru-Turaşl1, N. (2006). 6 yaş grubu çocuklarda benlik algısını desteklemeye yönelik Sosyal-Duygusal Hazırlı Programının etkililiğinin incelenmesi. Yayımlanmamış doktora tezi, Marmara Üniversitesi Eğitim Bilimleri Enstitüsü, İstanbul.

Kuru-Turaşlı, N. (2014). Okul öncesi eğitimin tanımı, kapsamı ve önemi.G. Haktanır (Ed.) Okul öncesi eğitime giriş. içinde (s.1-24). Ankara: Anı Yayıncılık.

Matthews, J.S., Ponitz, C.C.\& Morrison, F.J. (2009). Early gender differences in self-regulation and academic achievement. Journal of Educational Psychology, 101(3), 689-704.

Mercan, M. (2019). Okul öncesi eğitim kurumlarına devam eden 5-6 yaş çocuklarının öz düzenleme becerileri ile akademik benlik saygıları ve kişilerarası problem çözme becerileri arasındaki ilişkinin incelenmesi. Yayınlanmamış yüksek lisans tezi, Gazi Üniversitesi Eğitim Bilimleri Enstitüsü, Ankara.

Özbey, S. (2018). Okul öncesi dönem çocuklarında motivasyon ve öz düzenleme becerileri üzerine bir inceleme. Akademik Sosyal Araştırmalar Dergisi (ASOS Journal), 65, 26-47.

Polat, Ö. ve Akşin, E. (2015). A study of the relationship between self-concept and primary school readiness in 60- 72 month-old children and the analysis of their primary school readiness and self concept according to some variables. European Journal of Research on Education, 3(2), $14-21$.

Sarıca, Ö. (2010). Okul öncesi eğitim kurumlarına devam eden 5 ve 6 yaş grubu çocuklarının benlik kavramlarının çeşitli sosyo-demografik değişkenlere göre incelenmesi. Yayımlanmamış yüksek lisans tezi, Maltepe Üniversitesi Sosyal Bilimler Enstitüsü, İstanbul.

Schunk, D. H., \& Zimmerman, B. J. (Eds.). (2001). Self-regulated learning: From teaching to self reflective practice. UK: Guilford Press.

Senemoğlu, N. (1994). Okul öncesi eğitim programı hangi yeterlilikleri kazandırmalı? Hacettepe Üniversitesi Ë̆itim Fakültesi Dergisi, 10, 21-30.

Shonkoff, J. P., \& Phillips, D. A. (2000). From neurons to neighborhoods: The science of early childhood development. Washington, DC: National Academy.

Skibbe, L. E., McDonald Connor, C., Morrison, F. J., \& Jewkes, A. M. (2011). Schooling effects on preschoolers' self-regulation, early literacy, and language growth. Early Childhood Research Quarterly, 26, 42-49.

Sümer, N. ve Anafarta Şendağ, M. (2009). Orta çocukluk döneminde ebeveynlere bağlanma, benlik algis1 ve kayg1. Türk Psikoloji Dergisi. 24(63), 86-101.

Şanlı, Z.S. (2012). Probleme Dayalı Altı Aşamalı Ders İşleme Modelinin anaokuluna giden 60- 72 aylık çocukların benlik algılarına etkisi. Yayımlanmamış yüksek lisans tezi, Hacettepe Üniversitesi Sosyal Bilimler Enstitüsü, Ankara.

Şepitci-Sarıbaş, M. ve Gültekin-Akduman, G. (2019). 5-6 yaş çocuklarının öz düzenleme becerilerinin okul uyumu ile ilişkisi. Uluslararası Sosyal Araştırmalar Dergisi, 12(63), 867-883.

Tutkun, C.; Tezel-Şahin, F. ve Işıktekiner, S. (2016). Dört-beş yaş çocuklarının öz düzenleme becerilerinin incelenmesi. Ö. Demirel ve S. Dinçer (Ed.), Eğitim bilimlerinde yenilikler ve nitelik arayışı. içinde (s.459-473). Ankara: Pegem Akademi.

Türkmen, S.ve Özbey, S. (2018). 60-72 aylık okul öncesi dönem çocuklarının benlik algılarının bazı değişkenler ve motivasyon düzeyi ile ilişkisinin incelenmesi. Social, Mentality and Researcher Thinkers Journal, 4(12), 606-620. 
Yakupoğlu, Y. (2011). Erken çocukluk döneminde yer alan, okulöncesi eğitim kurumuna devam eden çocukların benlik kavramı algısıyla babalarının bağlanma stillerinin (güvenli-korkulukayltsı-saplantıll) arasındaki ilişkinin incelenmesi. Yayımlanmamış yüksek lisans tezi, Maltepe Üniversitesi Sosyal Bilimler Enstitüsü, İstanbul.

Yaralı, K. (2015). Okul öncesi eğitime devam eden 5-6 yaş çocuklarının bilişsel tempolarına göre benlik algılarının incelenmesi. Yayımlanmamış yüksek lisans tezi, Gazi Üniversitesi Eğitim Bilimleri Enstitüsü, Ankara.

Yorulmaz, Z. (2017). Okul öncesi ögrencilerinin benlik algılarının ve sosyal uyumlarının bazı değişkenlere göre incelenmesi. Yayımlanmamış yüksek lisans tezi, Karadeniz Teknik Üniversitesi, Eğitim Bilimleri Enstitüsü, Trabzon.

Yukay-Yüksel, M. ve Yıldırım-Kurtuluş, H. (2016). Okul öncesi dönemdeki 4-5 yaş grubu öğrencilerin benlik kavramı ve bağlanma stillerinin anne davranışları açısından incelenmesi. Ĕ̈itim ve Öğretim Araştırmaları Dergisi, 5(2), 182-195.

Zembat, R., Koçyiğit, S., Akşin-Yavuz, E. ve Tunçeli, H.İ. (2018). Çocukların benlik algısı, mizaç ve sosyal becerileri arasındaki ilişkiler. Uluslararası Türkçe Edebiyat Kültür Eğitim Dergisi, $7(1), 548-567$.

Zembat, R., Kuru-Turaşl1, N., Güven, G., Sezer, T., Akşin, E., Yılmaz, E. ve Bayındır, D. (2016). Validity and reliability of the DeMoulin Self-Concept Developmental Scale for the 36-72 Month Old Children. Journal of Education and Training Studies. 4(2), 143-158.

Zimmerman, B.J. (1989). A social cognitive view of self-regulated academic learning. Journal of Educational Psychology, 81, 329-339.

Zimmerman, B.J. (2000). Attaining self-regulation: A social cognitive perspective. In M. Boekaerts, P. R. Pintrich, \& M. Zeidner (Eds.), Handbook of self-regulation (pp. 13- 39). San Diego, CA, USA: Academic Press.

Zincirkıran, Z. (2008). Okul öncesi eğitim kurumlarına devam eden 6 yaş grubu çocuklarının benlik kavramlarının bazı değişkenlere göre incelenmesi. Yayımlanmamış yüksek lisans tezi, Maltepe Üniversitesi Sosyal Bilimler Enstitüsü, İstanbul. 